\title{
Valorization of Waste Feathers in the Production of New Thermal Insulation Materials
}

\author{
Elena Dieckmann ${ }^{1,2,4} \cdot$ Richard Onsiong $^{4} \cdot$ Balázs Nagy $^{3} \cdot$ Leila Sheldrick $^{1} \cdot$ Christopher Cheeseman $^{4}(1)$
}

Received: 6 December 2019 / Accepted: 7 March 2020 / Published online: 18 March 2020

(c) The Author(s) 2020

\begin{abstract}
Poultry has become the primary source of dietary protein consumed globally and as a result the by-product feathers are an increasingly problematic industrial waste. Developing a circular economy for feathers is, therefore, an important research area that provides an opportunity to make use of the unique combination of properties of this abundant natural material. This paper reports on the thermal properties of novel feather-based thermal insulation materials. Waste feathers were collected, cleaned and processed into fibres, which were then used to form air-laid nonwoven materials. These have a high fibre content and exploit the excellent natural thermal insulation properties of feathers. The performance of the novel materials developed are tested in order to outline the influence of temperature and density on thermal conductivity and dynamic water sorption. Results are compared to a range of commercially available thermal insulation materials for buildings manufactured from denim, hemp, sheep wool, PET and mineral wool. It was found that air laid feather-fibre fabrics have comparable performance to other fibrous materials and have a thermal conductivity of $0.033 \mathrm{~W} /(\mathrm{m} \mathrm{K})$ for samples with a density of $59 \mathrm{~kg} / \mathrm{m}^{3}$. This is due to the low thermal conductivity of feather fibres and the void structure formed by air-laid processing that effectively traps air. These materials additionally offer improved sustainability credentials as they are derived from a readily available waste that is generally considered to be unavoidable. The paper concludes by highlighting the significant technical and commercial barriers that exist to using waste feathers in thermal insulation products and suggests areas for further research that can exploit the unique properties of feathers.
\end{abstract}

\section{Graphical Abstract}

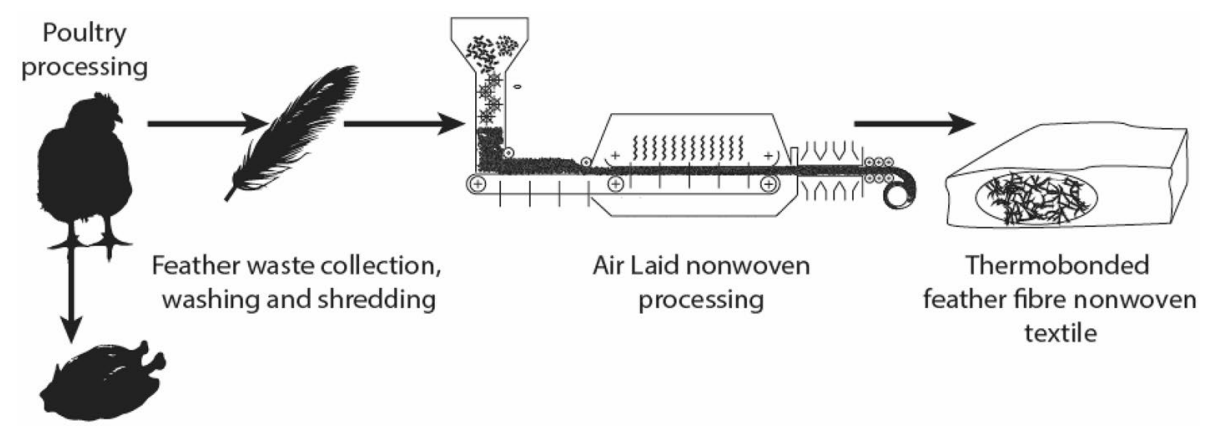

Keywords Poultry $\cdot$ Feathers · Thermal insulation · Fibres · Sustainable materials · Circular economy $\cdot$ Barriers to use Energy efficiency

\section{Christopher Cheeseman \\ c.cheeseman@imperial.ac.uk}

Extended author information available on the last page of the article

\section{Statement of Novelty}

This research was completed because globally we consume increasing amounts of poultry and as a result the volumes of waste feathers are increasing. Feathers have a unique 
combination of properties and these can be exploited by developing new materials. A key characteristic of feathers is their excellent thermal insulation properties. This work has developed novel thermally insulating feather textiles. The performance of these has been tested and compared to other commercially available thermal insulation materials. The impact of the research is the development of a new reuse technology for feathers. The paper also examines potential barriers to using feathers in this application in the UK and these are significant. This highlights major issues associated with valorisation of waste feathers.

\section{Introduction}

Feathers are one of the most effective thermal insulation materials, with thermal conductivities ranging from $0.024 \mathrm{~W} /(\mathrm{m} \mathrm{K})$ and $0.034 \mathrm{~W} /(\mathrm{m} \mathrm{K})$ depending on the type of feather [1]. The low thermal conductivity of feathers results from their chemical composition and microstructure, which effectively traps air and produces a highly effective thermal barrier. The different parts of contour feathers are shown in Fig. 1. They consist of a tough central quill and rachis, connected to soft interlinking barbs that form the vanes. Feathers are robust, tough and resilient to loading and this enables them to recover their original shape and retain function.

The main structural component in feathers is a mix of $\alpha$-keratin and $\beta$-keratin. Chicken feathers have typical elemental composition of (wt $\%$ ): $47.4 \% \mathrm{C} ; 7.2 \% \mathrm{H} ; 15.1 \% \mathrm{~N}$; $2.9 \% \mathrm{~S} ; 27.4 \%$ other (O and inorganic matter) [2]. Thermal degradation in a $\mathrm{N}_{2}$ atmosphere occurs at $\sim 180{ }^{\circ} \mathrm{C}$ [3] and this limits the use of higher temperature processing options. Feathers have a skeletal density of $\sim 1.01 \mathrm{~g} / \mathrm{cm}^{3}$ compared to $\sim 1.50 \mathrm{~g} / \mathrm{cm}^{3}$ for cellulose fibres, $1.30 \mathrm{~g} / \mathrm{cm}^{3}$ for wool fibres and $1.39 \mathrm{~g} / \mathrm{cm}^{3}$ for hemp fibres [4, 5], and the encapsulated voids in the porous microstructure make feathers one of the lightest natural materials with a density of $0.68 \mathrm{~g}$. $\mathrm{cm}^{-3}[4]$.
Fig. 1 Feather structure consisting of a hollow shaft (Quill) and rachis, with the vane consisting of barbs and barbules

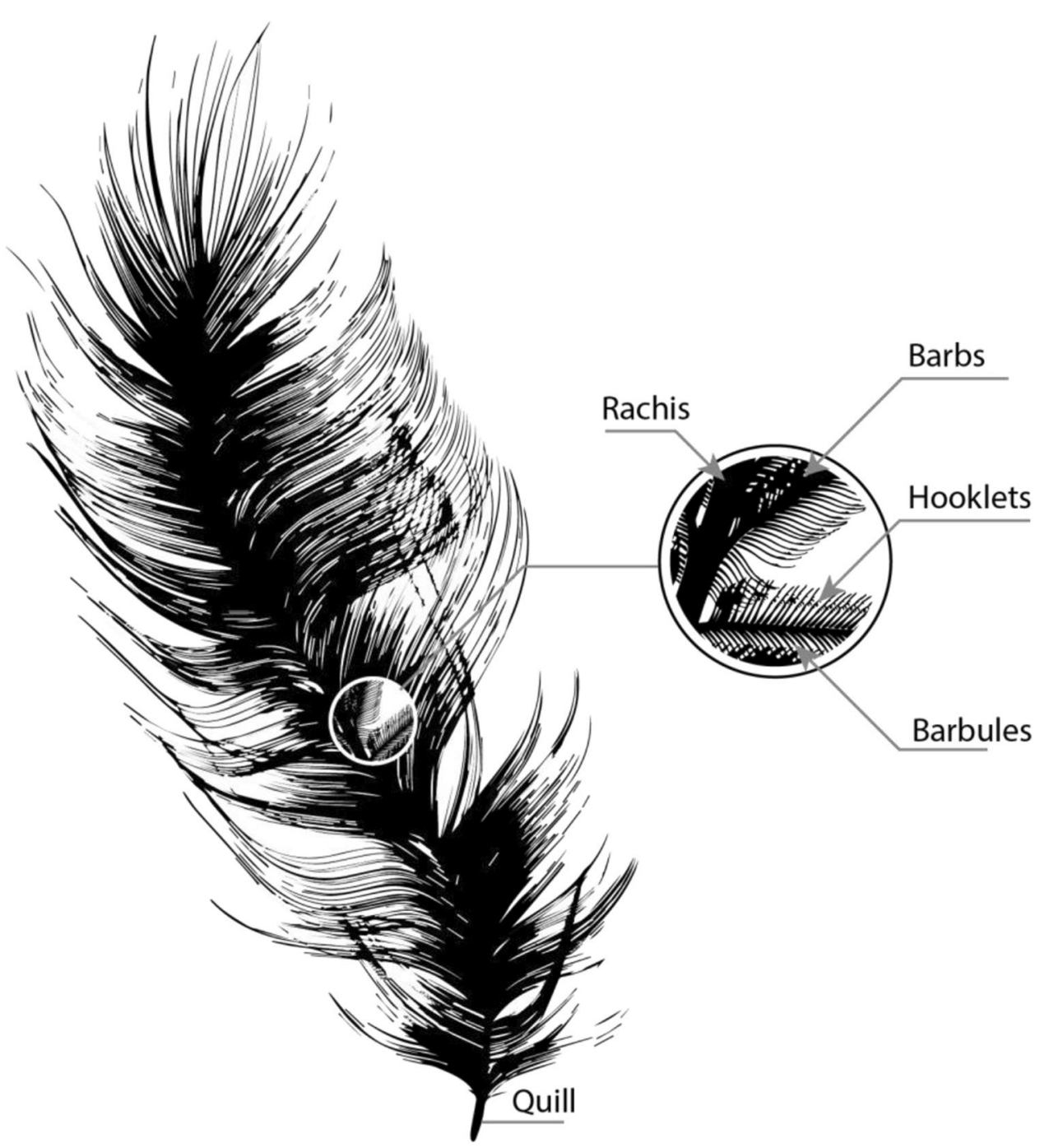


Feathers are an abundant waste from the poultry industry and developing a circular economy to take advantage of their unique natural properties has potential to provide a sustainable alternative to current, predominantly linear, disposal methods. Poultry consumption is increasing globally, due to the relatively low-costs associated with poultry farming and the rapid growth of chickens. Europe consumes an estimated 14,013,000 tonnes of poultry per annum [6]. The UK is a significant producer and consumer of chicken, and it is reported that $\sim 100$ million birds are currently processed every month [7]. Global poultry consumption is expected to increase to $\sim 14.9 \mathrm{~kg} /$ person/year by 2023 , and this will make poultry the primary source of animal-derived dietary protein [8]. Poultry industry produces $\sim 3.1$ million tonnes of waste feathers per annum in the EU, and as a result research to develop novel applications for feathers has increased in recent years [9-18]. However, limited applications for feathers currently exist and developing new materials that exploit the properties of this novel material is an important area for further work.

The low thermal conductivity of feathers make them potentially ideal for use in thermal insulation applications. Thermal insulation is critical to buildings and is also important in aerospace and automotive sector and in thermal packaging. The global market for thermal insulation materials for use in buildings is expected to reach USD 28.39 billion in 2021 [19]. The majority of thermal insulation materials are currently synthetic plastic-based materials or mineral/glass wool, and these are associated with various adverse environmental impacts, particularly at end of life [20]. Therefore, industry, architects and consumers are increasingly seeking more sustainable thermal insulation materials that are derived from natural or recycled materials.

The thermal conductivity of sustainable building insulation products have been reviewed and these are being used in a range of applications to achieve energy efficiency targets [21]. The thermal conductivity, thermal diffusivity and water vapour permeability of natural insulators have been reported and sensitivity to humidity is known to reduce the thermal performance [22,23]. The thermal conductivity and mechanical properties of lightweight cementitious materials material containing fibres such as recycled paper mill waste have also been reported [24].

Many commercial insulation products are supplied as mats and fabrics that are manufactured using textile processing of fibres to form lofty, stable, dust-free, air-trapping structures. Non-woven production processes use needlepunching, wet-laying, air laying, spun-laying and dry laying to form textiles, and the process selected determines the properties and microstructure of the materials formed. Recent research into these materials has found that fibrous thermal insulation building materials are permeable to water vapour and hygrothermal properties have been reported
[25]. The thermal characteristics and physical properties of insulation materials made from textile wastes using needlepunching technology have been determined and the materials formed were considered viable materials for use in building thermal insulation [26]. Non-woven thermal insulation materials have also been prepared from wool and recycled polyester fibres and the layered composite materials formed were considered suitable for insulating green buildings [27]. Regardless of manufacturing processes, the thermal conductivity and hygroscopic properties are critical to the performance of thermal insulation materials and need to be assessed in the development of new sustainable natural alternative products.

Waste feathers offer a unique opportunity to create new thermally insulating materials. They are similar in chemical composition to wool but have a different structure. They have additional technical challenges in non-woven composite production associated with their low-density and relatively short fibre length. In this research, air laid processing was selected to manufacture new feather fibre materials. Air laid processing was selected because it can use short and light fibres and has the ability to produce materials with extremely high fibre loadings. In addition, materials with different densities and thickness can be formed, depending on the applied processing conditions.

The sound insulation properties of non-woven mats made from air-laid chicken fibres have previously been reported [28-30]. This research builds on this previous work and reports specifically on the thermal properties of novel feather fibre air-laid materials. The aim of the research was to assess the potential for valorization of waste feathers in the production of new thermal insulation materials. The following sections describe the methods used to produce and test new air-laid non-woven feather fibre fabrics and the results of experiments conducted to determine thermal and hygroscopic properties. The results are compared to the performance to commercially available fibrous thermal insulation products. The closing section of the paper discuss and assess the barriers to producing commercially viable thermal insulation products from the waste feather fibres used in this research.

\section{Experimental Section}

This research involved experimentation across the whole supply chain of feather waste, from sourcing feather waste to material production. The work reported in this paper describes how thermally optimised feather fibre fabrics were produced and tested, as shown in Fig. 2. The following sections further outline the material development and testing methodologies employed. 


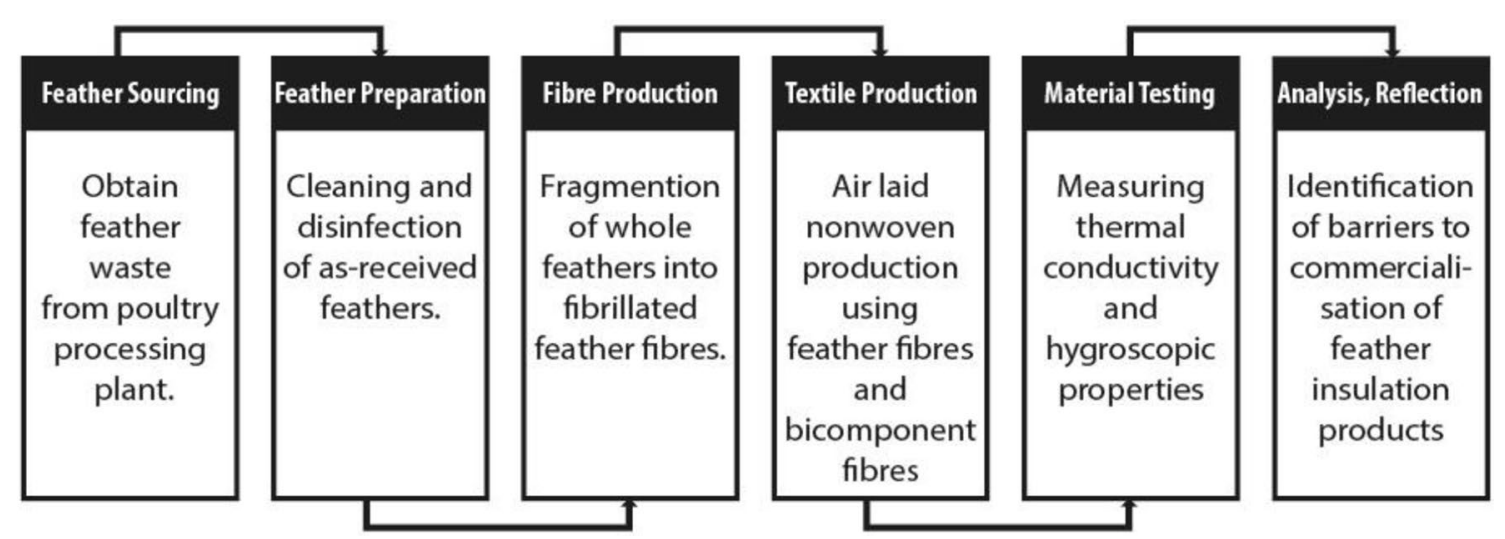

Fig. 2 Phases of work for development of air laid nonwoven feather fibre fabrics for thermal insulation

\section{Materials}

Waste chicken feathers were obtained from a major UK poultry processing facility that produces approximately 160 tonnes of wet soiled by-product feathers a week. The chicken feathers obtained were thoroughly washed using a $5 \%$ hydrogen peroxide solution containing an industrial scouring agent (M-SCOUR F-5, Regency FCB) and treated using $1 \%$ disinfectant solution (Dupont Virkon S) and dried. They were then granulated using a Rapid 2040 granulator that produces feather fibres suitable for use in the air-laid process. The feather fibres were then mixed to form a 90:10 mix (by mass) of feather-fibres and bi-component fibre. The bi-component fibre had a polyethene (PE) surface and a polypropylene (PP) core and were $6 \mathrm{~mm}$ long with two denier and circular cross-section (AL-Thermal, 1.7 dtex, Fibervisions). The bi-component fibres partially melt and bind the featherfibres together at the temperatures and pressures used in the air-laid process. Epoxy resins have been used in the past to bind feather-fibres but the thermosetting resin causes thermal bridging, increasing thermal conductivity and reducing thermal insulation performance [31].

Air laid nonwoven feather fibre fabrics were produced at a commercial pilot plant facility using the process shown in Fig. 3. The bed of mixed fibres was heated to $\sim 145{ }^{\circ} \mathrm{C}$ as it moves under the heating hood and this produced airlaid nonwoven fabric mat with a density of $29.83 \mathrm{~kg} / \mathrm{m}^{3}$, as shown in Fig. 4a. The feather textiles were examined using scanning electron microscopy (SEM, Hitachi TM4000Plus) and a typical region is shown in Fig. $4 \mathrm{~b}$.

The properties of the air-laid nonwoven feather fibre fabric mats were compared to commercially available thermal insulation materials. All test samples were preconditioned for seven days at $23{ }^{\circ} \mathrm{C}$ and $\sim 40 \% \mathrm{RH}$ and the density determined from the mass (Mettler Toledo ME54E) and volume following EN 1602. The commercial

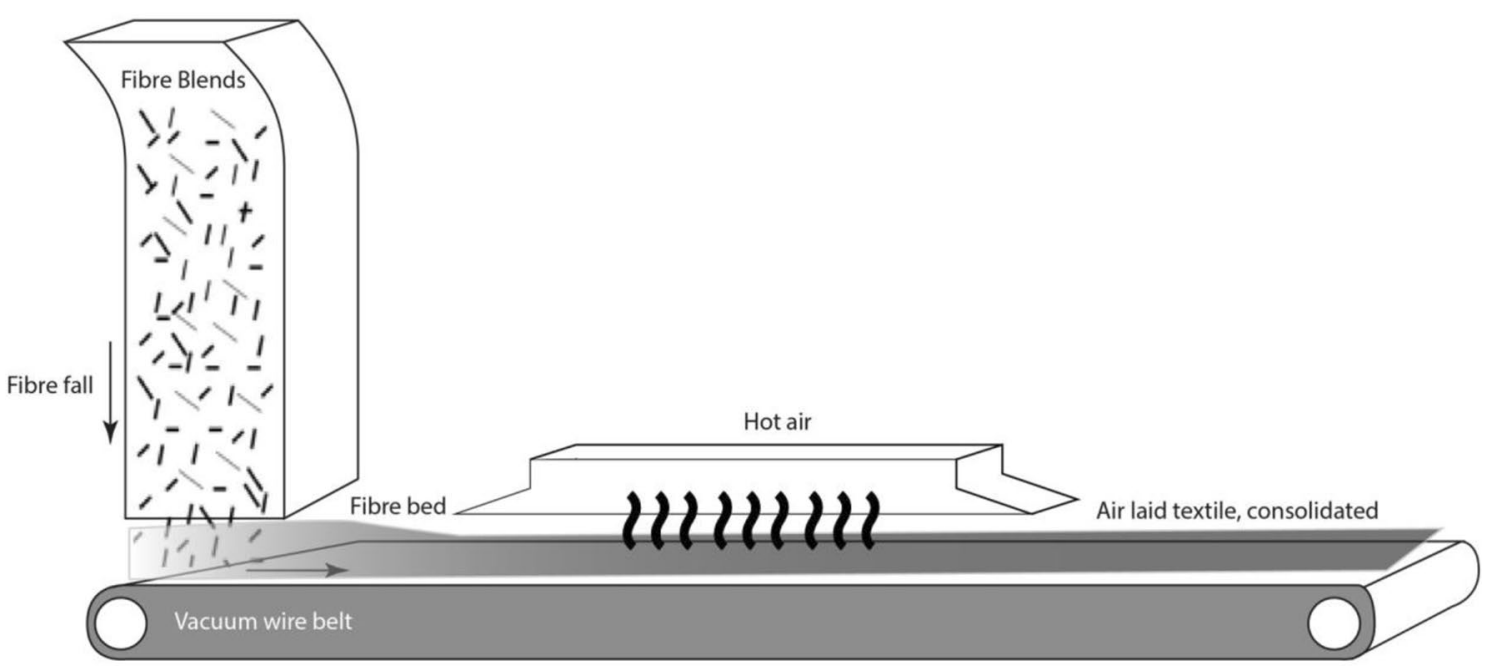

Fig. 3 Schematic diagram showing the air laid process used to form non-woven feather fibre composites 


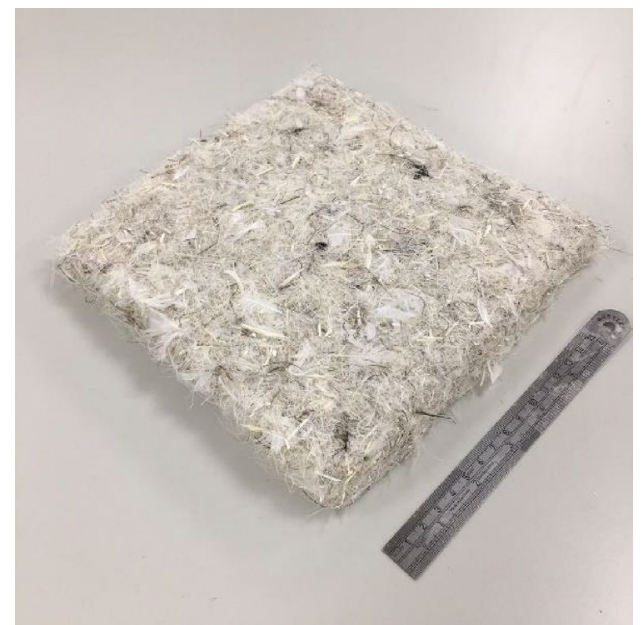

(a) Feather fibre fabric, density $29.8 \mathrm{~kg} / \mathrm{m}^{3}$

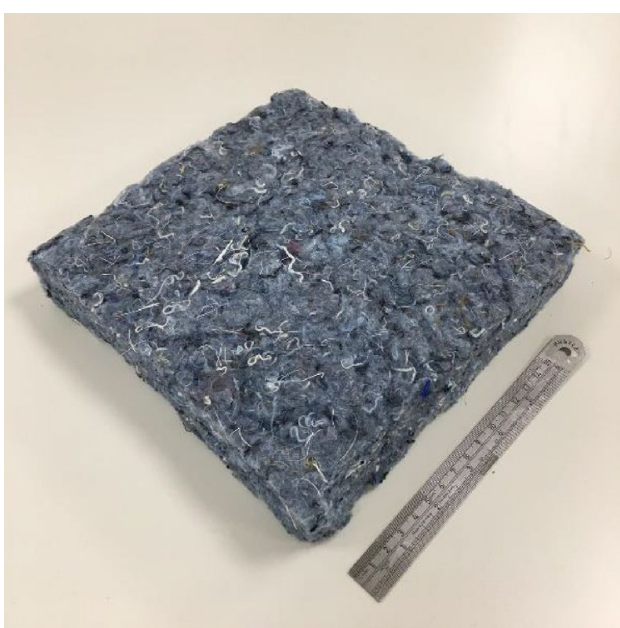

(c) Denim fabric, density $30.0 \mathrm{~kg} / \mathrm{m}^{3}$

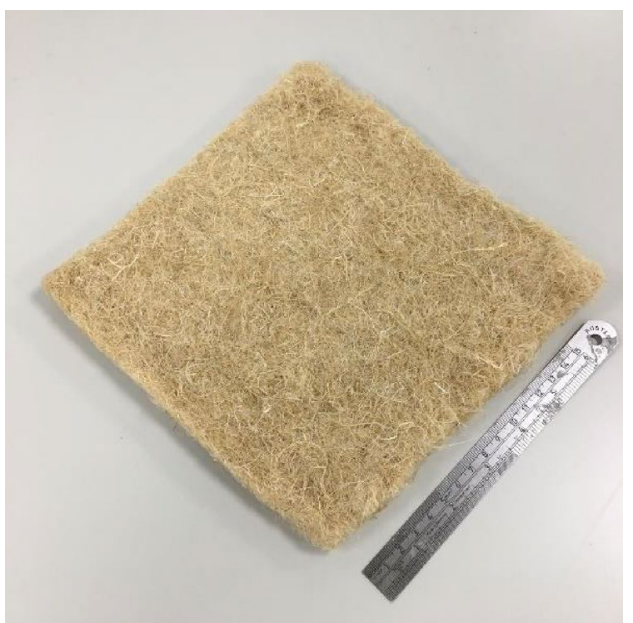

(e) Hemp fabric, density $83.3 \mathrm{~kg} / \mathrm{m}^{3}$

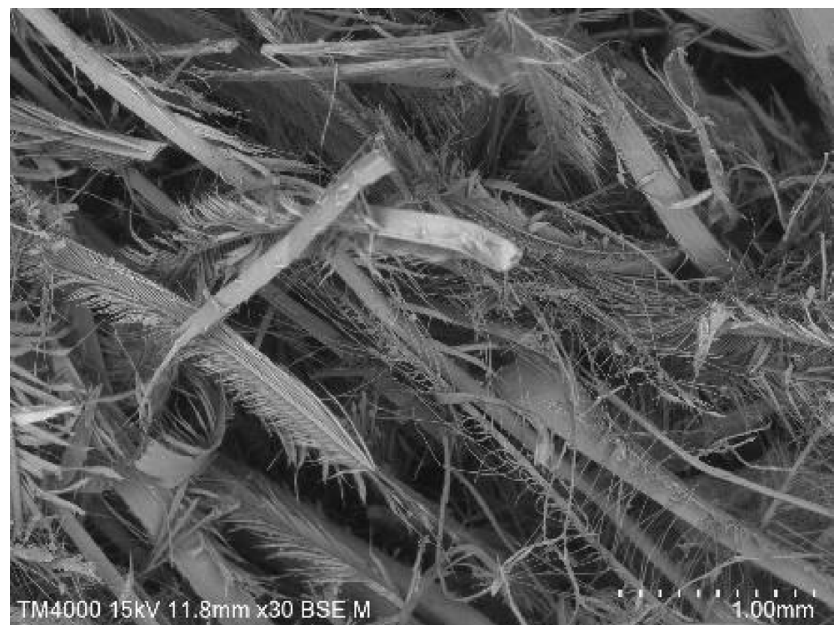

(b) Feather fibre fabric SEM image

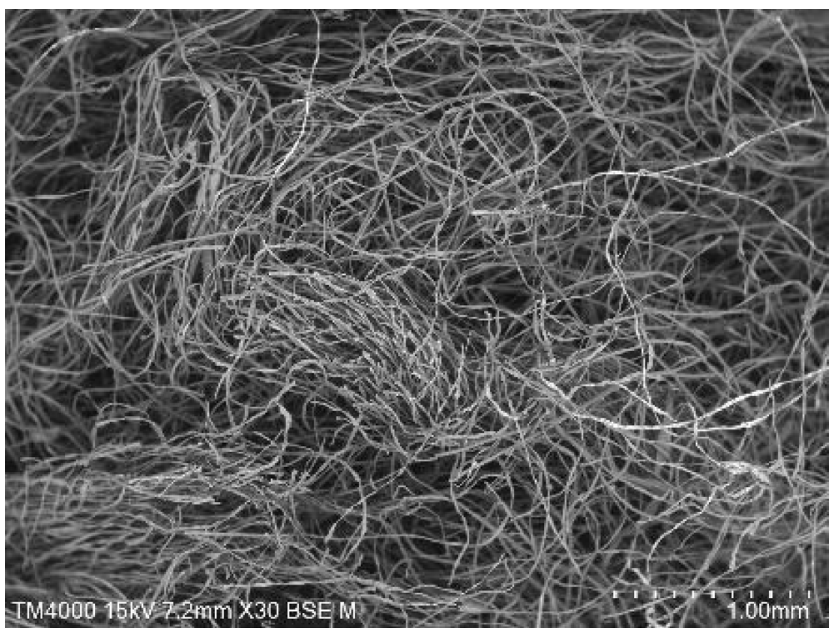

(d) Denim fibre fabric SEM image

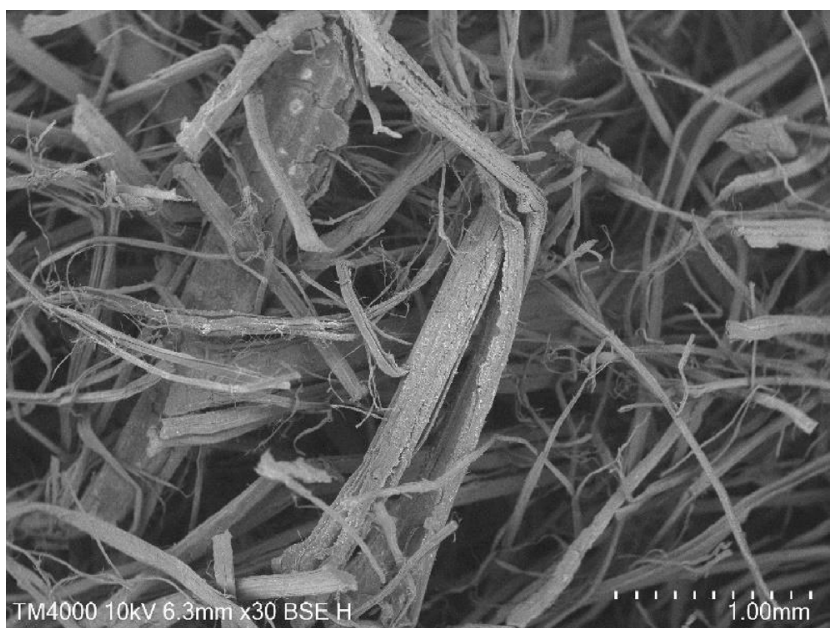

(f) Hemp fibre fabric SEM image

Fig. 4 Images of the feather fibre fabric produced in this study and the commercially available thermal insulation materials tested for comparison. Scanning electron microscope images of the microstructure of each material are also shown 


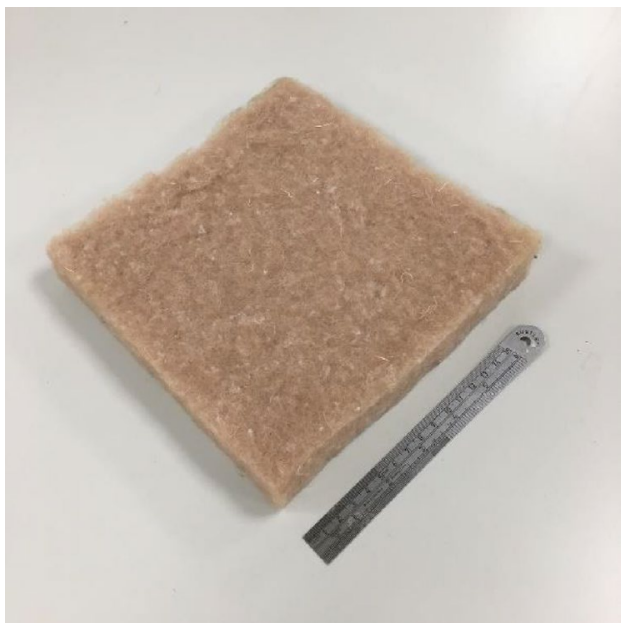

(g) PET fabric, density $25.5 \mathrm{~kg} / \mathrm{m}^{3}$

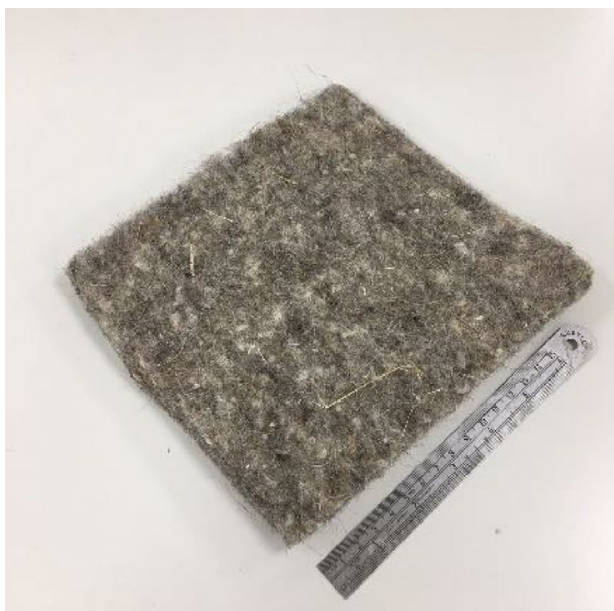

(i) Sheep wool fabric, density $47.6 \mathrm{~kg} / \mathrm{m}^{3}$

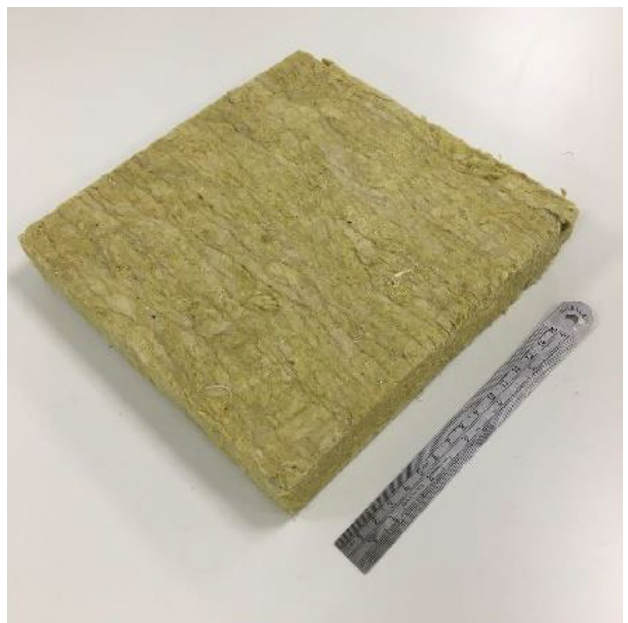

(k) Rock wool, density $110.3 \mathrm{~kg} / \mathrm{m}^{3}$

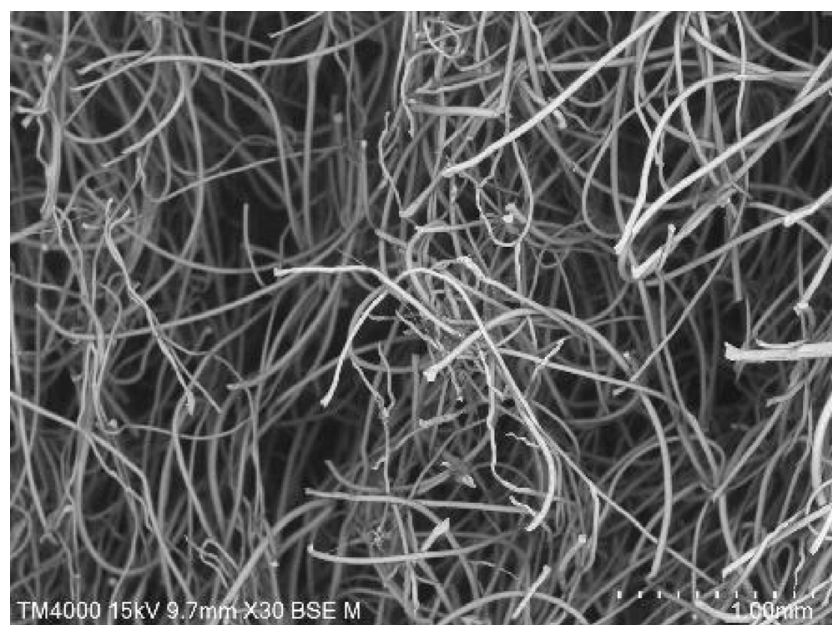

(h) PET fabric SEM image

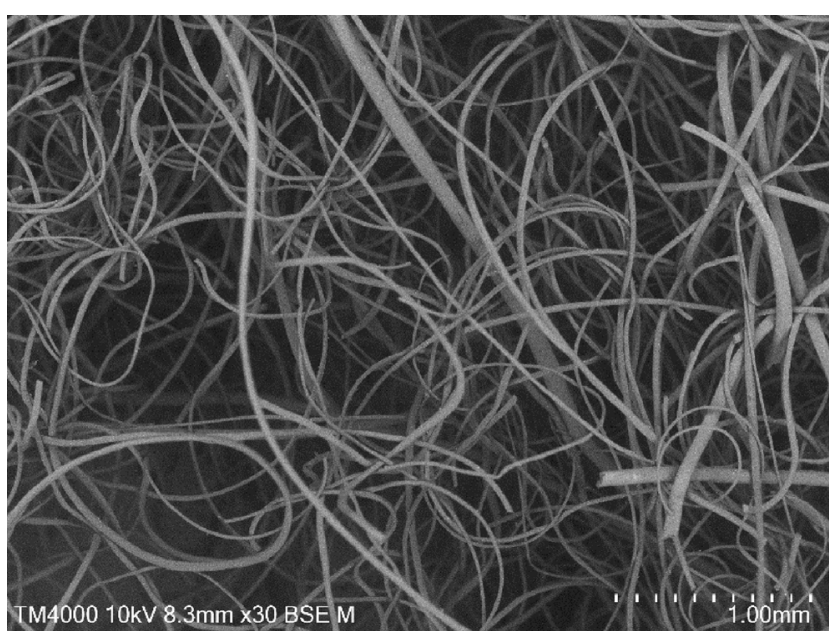

(j) Sheep wool SEM image

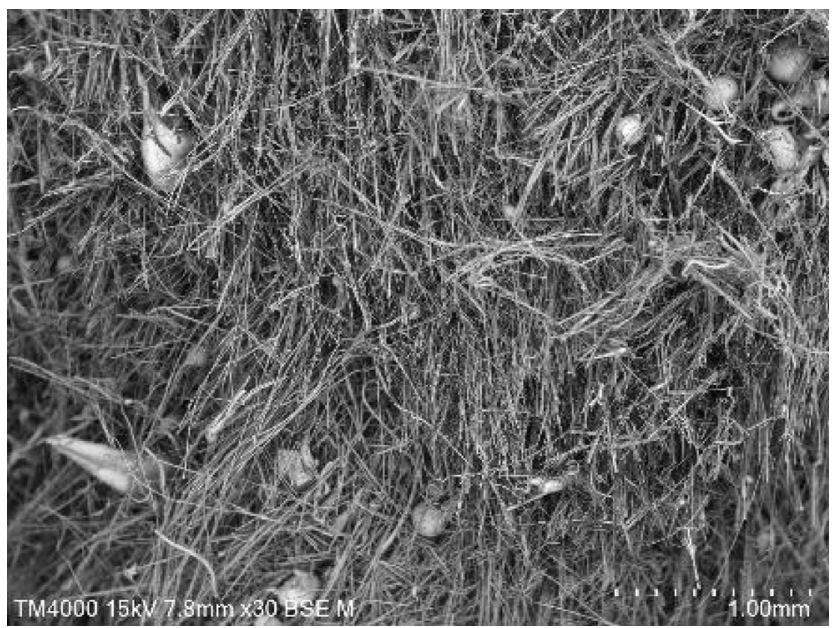

(l) Rock wool SEM image

Fig. 4 (continued)

samples tested were made from denim (density $30.00 \mathrm{~kg}$ / $\left.\mathrm{m}^{3}\right)$, hemp $\left(83.33 \mathrm{~kg} / \mathrm{m}^{3}\right)$, recycled polyethene terephthalate $\left(25.54 \mathrm{~kg} / \mathrm{m}^{3}\right)$, sheep's wool $\left(47.63 \mathrm{~kg} / \mathrm{m}^{3}\right)$ and mineral wool $\left(110.35 \mathrm{~kg} / \mathrm{m}^{3}\right)$ and the samples are also shown in Fig. 4. 


\section{Methods}

The thermal conductivity $(\lambda)$ is defined as the rate of steady state heat flow through a unit area of a homogeneous material induced by a unit of temperature gradient in a direction perpendicular to the unit area and is given by:

$\lambda=q \frac{d}{\Delta T}$

where $\mathrm{d}$ is the sample thickness $(\mathrm{m}), \Delta \mathrm{T}$ is the temperature difference across the sample $(\mathrm{K})$, and $\mathrm{q}$ is the heat flux (W/ $\mathrm{m}^{2}$ ). When a state of equilibrium is reached the rate of heat flow is constant, and the thermal conductivity $(\mathrm{W} /(\mathrm{m} \mathrm{K})$ ) can then be calculated.

Thermal conductivity was determined using a heat flow meter (Netzsch HFM 446). Test specimens with dimensions of $20 \times 20 \mathrm{~cm}$ and thickness $\sim 30 \mathrm{~mm}$ were placed in contact with the upper and lower hot and cold plates, which were then stabilised at different temperatures. The imposed temperature gradient causes heat to flow through the test specimen. Temperature and heat flux readings were recorded and used to calculate the thermal conductivity of specimens under steadystate conditions (EN ISO 12667). A temperature difference $(\Delta \mathrm{T})$ of $10 \mathrm{~K}$ was used between the hot and cold plates. This $\Delta \mathrm{T}$ and the selected mean sample temperatures limits condensation of water droplets on the cold plate and reduces measurement errors. The thermal conductivity varies with temperature and therefore it is important to determine how this property changes for the different materials tested. Therefore, mean test temperatures of $10{ }^{\circ} \mathrm{C}, 15{ }^{\circ} \mathrm{C}, 20^{\circ} \mathrm{C}, 25^{\circ} \mathrm{C}$ and $30^{\circ} \mathrm{C}$ were used to determine the variation in thermal conductivity with temperature. The samples were tested over the range of temperatures without being removed from the heat flow meter.

The distance between the hot and cold plates in the HFM determines the thickness of the test sample. Sample thickness can be changed by applying a load, allowing the sample density to be varied. Therefore the effect of average sample density on thermal conductivity was investigated at $20^{\circ} \mathrm{C}$, also using a $\Delta \mathrm{T}$ of $10 \mathrm{~K}$.

The top surface of different thermal insulation materials tested were examined using scanning electron microscopy (SEM, Hitachi TM4000Plus) to assess the fibre appearance, morphology and sample porosity.

The open-pore structure of fibrous insulators allows moisture to migrate into pores in the materials and be released when the humidity conditions change. The presence of water in thermal insulation significantly influences thermal conductivity, because water has a thermal conductivity of $\sim 0.6 \mathrm{~W} /(\mathrm{m} \mathrm{K})$, which is 20 times greater than the thermal conductivity of air. It is, therefore, essential to characterise the hygroscopic properties of thermal insulation materials [32].
Dynamic vapour sorption (DVS, Surface Measurement Systems, 2019) was used to accurately determine the change in mass of a sample exposed to water vapour and produce water vapour sorption isotherms. The device has a highly sensitive microbalance that measures the vapour sorption phenomena that occurs in samples with a volume of $\sim 0.5$ $\mathrm{cm}^{3}$ in a controlled constant-temperature incubator. The incubator temperature was held at $25^{\circ} \mathrm{C}$, and the vapour pressure was generated by mixing dry vapour gas and saturated gas flows in the correct proportions using a mass flow controller. This allowed vapour sorption curves to be determined for the different thermal insulation materials tested.

\section{Results}

Images of all the samples and the corresponding SEM images showing the fibre morphologies and microstructures are shown in Fig. 4c-l. The different thermal insulation samples have very different fibre morphologies and fibre distributions within the materials, with the overall sample density depending on the fibre density and packing, with all samples containing significant air void space. The air-laid feather fibre sample has a density of $29.8 \mathrm{~kg} / \mathrm{m}^{3}$, the given a feather density of $0.68 \mathrm{~g} / \mathrm{cm}^{3}$ and the reported density of the bico is $1155 \mathrm{~kg} / \mathrm{m}^{3}$ (AL-Thermal Fibervisions). The derived porosity of the textile is $95.9 \mathrm{vol} \%$.

Figure 5a shows the thermal conductivity of the different materials tested between 10 and $30^{\circ} \mathrm{C}$, using a $\Delta \mathrm{T}$ of $10 \mathrm{~K}$. The thermal conductivity increases with the test temperature for all the materials tested. PET has the highest thermal conductivity. The feather fabric, hemp and denim have different thermal conductivities at $10{ }^{\circ} \mathrm{C}$ with the feather fabric having a thermal conductivity of $0.036 \mathrm{~W} /(\mathrm{m} \mathrm{K})$. They appear to converge in thermal conductivity to a value of approximately $0.040 \mathrm{~W} /(\mathrm{m} \mathrm{K})$ as the temperature increases to $30^{\circ} \mathrm{C}$. Sheep's wool had the lowest thermal conductivity of $0.032 \mathrm{~W} /(\mathrm{m} \mathrm{K})$ at $10{ }^{\circ} \mathrm{C}$, and this increased to $0.036 \mathrm{~W} /$ $(\mathrm{m} \mathrm{K})$ at $30^{\circ} \mathrm{C}$.

Figure $5 \mathrm{~b}$ shows the effect of sample density on thermal conductivity at $20^{\circ} \mathrm{C}$ for all the materials tested. The thermal conductivity decreases as the sample density increases until it reaches the optimum, which is a local minimum in the thermal conductivity - density data. The minimum thermal conductivity of $0.033 \mathrm{~W} /(\mathrm{m} \mathrm{K})$ for feather-fibre fabric corresponded to a density of $\sim 59 \mathrm{~kg} / \mathrm{m}^{3}$. A further increase in density results in a small increase in thermal conductivity to $0.034 \mathrm{~W} /(\mathrm{m} \mathrm{K})$. The sheep wool sample had the lowest thermal conductivity at $0.031 \mathrm{~W} /(\mathrm{m} \mathrm{K})$ with a density of $\sim 79 \mathrm{~kg} /$ $\mathrm{m}^{3}$. The rock wool sample did not change dimensions under the loads imposed in the HFM 446 and the density remained constant at $\sim 110 \mathrm{~kg} / \mathrm{m}^{3}$. 
Fig. 5 Thermal conductivity data for feather fibre fabric and commercially available thermal insulation materials (tested at $20^{\circ} \mathrm{C}, \Delta \mathrm{T}=10^{\circ} \mathrm{C}$ ). a Effect of test temperature on thermal conductivity, b effect of sample density on thermal conductivity
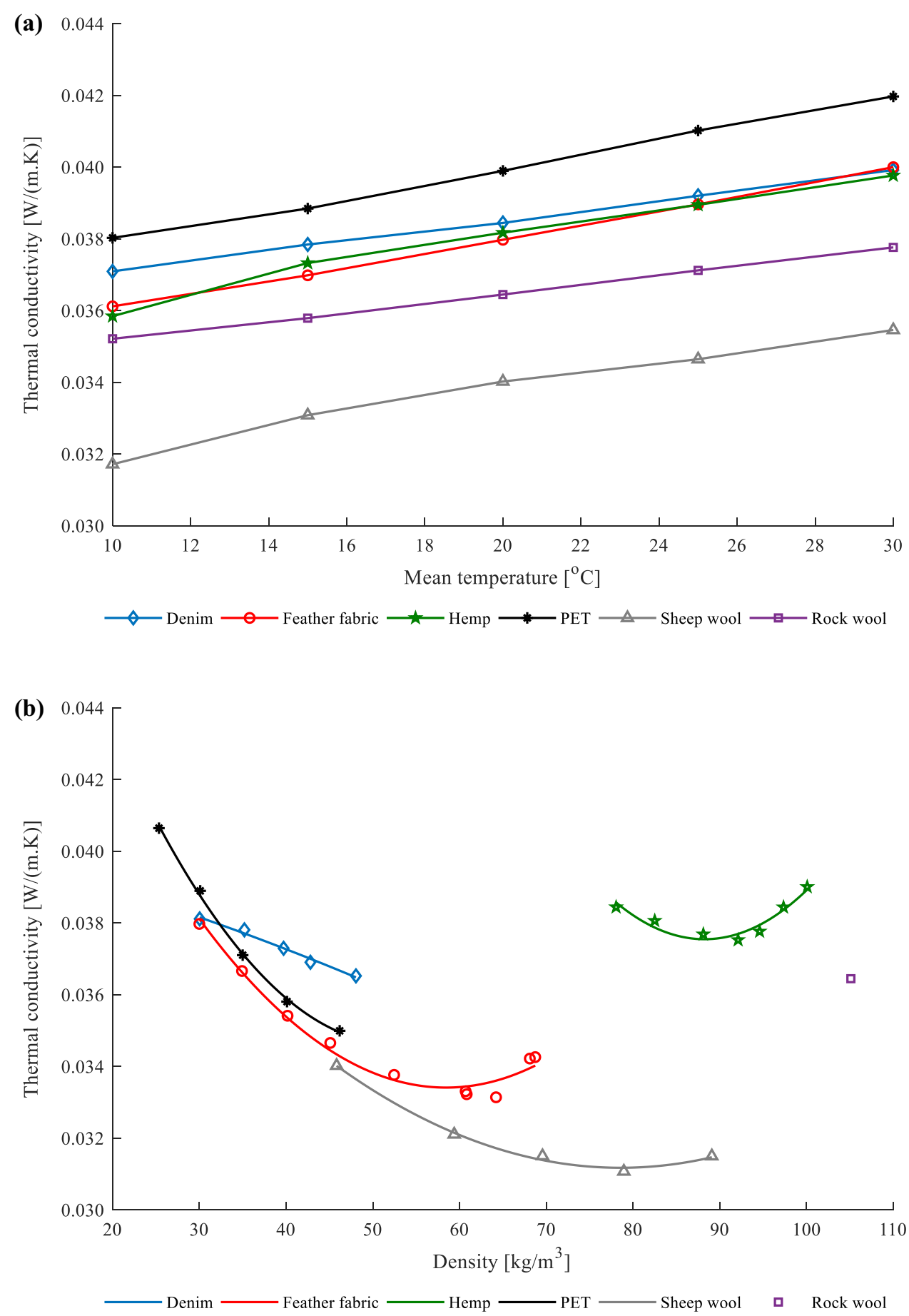

The thermal conductivity of fibrous insulation materials is determined by conduction, which involves molecular motion in solids transferring heat from hot to cold regions, and by convection, which is determined by air motion transferring heat through the material. Heat transfer by radiation in fibrous insulation is expected to be minimal for application temperature is under $100{ }^{\circ} \mathrm{C}$ [33].

The inherently low thermal conductivity of the types of fibres investigated means that the contribution from conduction is low. Increasing the sample temperature during thermal conductivity testing increases the gas conduction, convection and radiation, although changes in radiation will be very small in the temperature range examined (Fig. 5a). Increasing the sample density is likely to significantly reduce heat transfer by convection. This was confirmed, as the tests show a reduction in thermal conductivity (Fig. 5b). The exact behaviour depends on the fibre type and the specific relationship between density and microstructure. The lowest 
Fig. 6 DVS data for feather fibre fabrics and commercially available thermal insulation materials

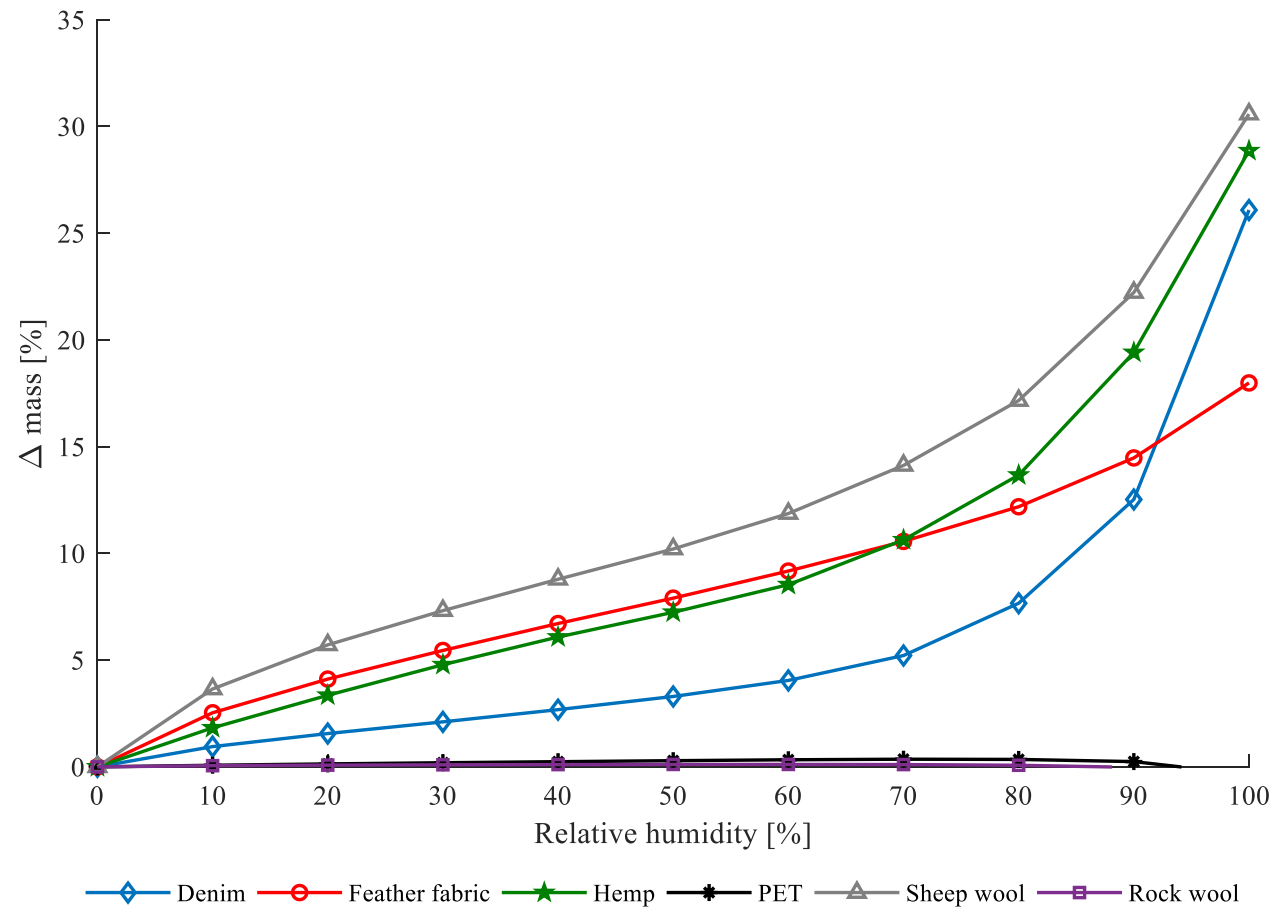

thermal conductivity for the feather fibre sample occurs at a density of $\sim 60 \mathrm{~kg} / \mathrm{m}^{3}$ and optimising processing to produce material at this density would therefore form the optimum feather fibre insulation.

Figure 6 shows the dynamic vapour sorption (DVS) data. Commercially available denim, hemp, sheep's wool and feather fibre fabric all adsorb moisture and increase in weight as the relative humidity increases. The feather fabric adsorbs marginally less moisture than denim, hemp or sheep's wool at high humidity, while denim and hemp adsorb less until $\sim 70 \% \mathrm{RH}$. At higher humidity it is likely that capillary condensation and liquid heat transfer start in these materials. Rockwool is usually hydrophobic until the RH exceeds $90 \%$, but at higher humidity it takes up some moisture and as a result, the thermal conductivity is expected to increase. The feather-fibre fabric behaves in a very similar way to other insulation materials made from natural fibres.

The mechanism for the change in mass of samples during isothermal water vapour sorption testing is shown in Fig. 7. Regions 1 and 2 of the moisture content-relative humidity graph are the hygroscopic regime, in which water molecules from the water vapour in the sample bond to fibre surfaces
Fig. 7 Mechanism for the change in mass of samples during isothermal water vapour sorption testing with visualisation of fibre interior, cross-sectional view. Region 1: water molecules bond to fibre surfaces; Region 2: additional water layers form with lower adhesion energy; Region 3: capillary condensation occurs causing a more rapid increase in moisture content and weight gain (Rode 2016)

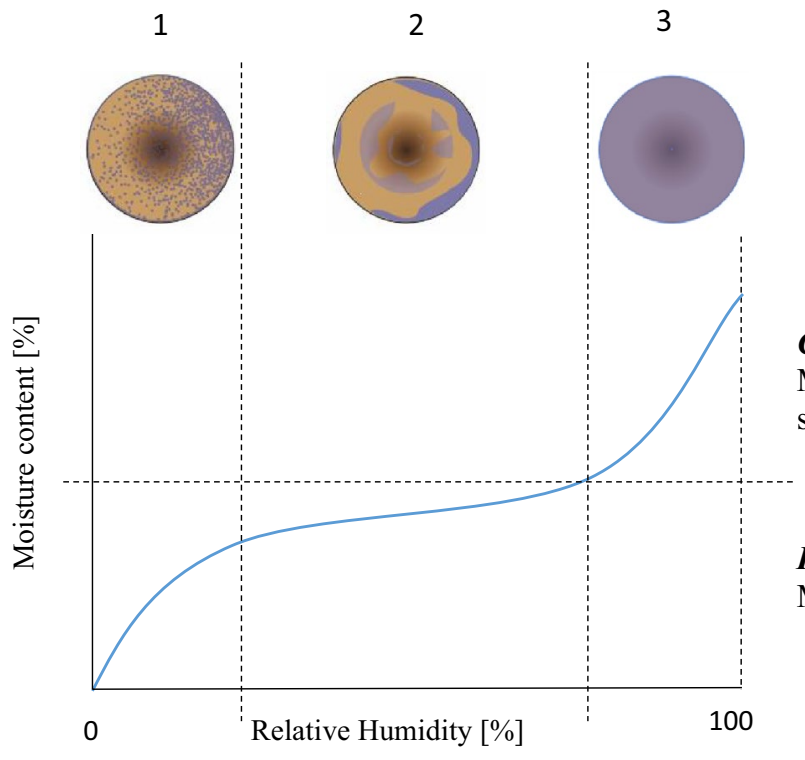

Capillary regime

Moisture is taken up with suction from condensation

Hydroscopic regime

Moisture is taken up from air 
through intermolecular Van der Waals forces. As the relative humidity increases region 2 forms in which additional layers of water molecules are produced with reduced adhesion energy. Region 3 is the capillary regime at relatively high humidity, and this is associated with capillary condensation, which causes a more rapid increase in moisture content and increase in sample mass.

The behaviour of PET and rock wool samples is very different, and they do not show any initial interaction with water molecules and as a result, show negligible weight increase with increasing relative humidity. PET (recycled polyester) is inherently hydrophobic, and mineral wool is subject to hydrophobic treatment during manufacturing. Hydrophobic oils are applied to reduce the impact of water ingress and moisture penetration.

Table 1 provides a summary of critical data from the thermal conductivity and dynamic vapour sorption tests. It shows that the experimental feather-fibre fabric sample prepared in this research have comparable thermal conductivity and water sorption properties to commercially available thermal insulation products currently on the market. The feather-fibre fabrics could be produced at higher density than the materials tested in these experiments, with minimal additional materials and processing costs. This would make feather-fibre thermal insulation products highly competitive, in terms of performance, with the best sustainable thermal insulation materials currently available.

\section{Discussion}

The production of thermal insulation materials from waste feathers has involved washing and disinfection, processing the clean and dry feathers into fibres and producing air-laid nonwoven feather-fibre materials at an industrial pilot-plant facility. Various processing parameters have been investigated by the authors [34] to determine the best binder materials, mixing ratios, mat thicknesses and other key factors for different applications. In order to achieve low thermal conductivity, feather-fibre textiles with low binder content were used to maximise the contribution from the natural properties of the feather fibres. Relevant material properties, including the effect of density on thermal conductivity and moisture sorption have been reported, and the results compared to commercially available fibre thermal insulation materials. A key conclusion is that it is technically feasible to manufacture high-performance thermal insulation materials from waste feathers with comparable properties to products manufactured from denim, hemp and wool.

The key question then is, why are feathers not being used to manufacture thermal insulation materials? Moreover, why has extensive research over many years [9-18] failed to develop a commercially viable circular economy for waste feathers? This research has involved investigating and prototyping the complete production chain for feather materials, from sourcing of industrial waste feathers, to pre-processing involving washing and disinfection, through to the production of novel air laid materials. This has identified a number of critical barriers to commercialisation.

One significant issue occurs with the source material. The vast majority of the approximately 1,000 tonnes per week of waste feathers generated by the UK poultry industry are in the form of a wet, soiled feather filter cake, as shown in Fig. 8. Feather waste is a Category III Animal By-Product and reuse options for this material are therefore severely limited. The most common outlet currently used involves rendering the feather cake waste to produce feather meal, a low-grade animal feed which is exported because

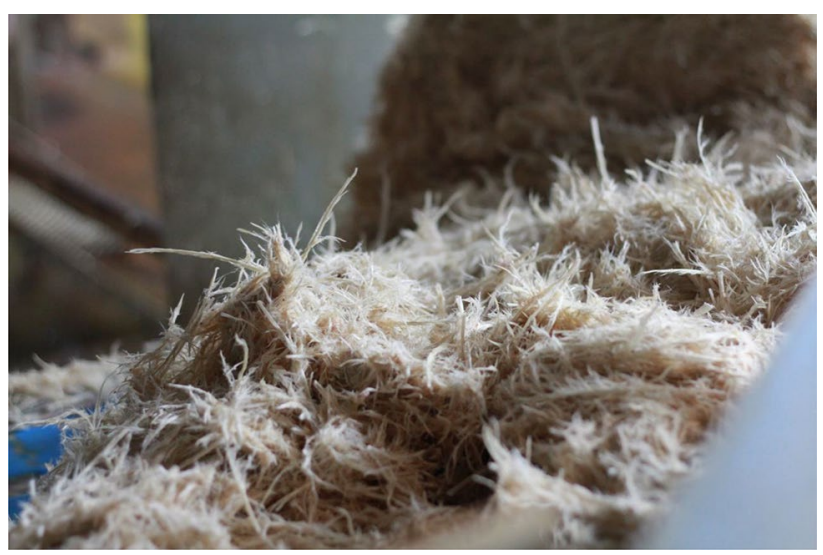

Fig. 8 Waste feather filter cake as typically produced at poultry processing facilities in the UK. This is contaminated and typically contains $\sim 50 \%$ by weight of water

Table 1 Summary of key thermal property characterisation results for different thermal insulation materials

\begin{tabular}{|c|c|c|c|c|c|c|}
\hline & Feather fibre & Denim & Hemp & PET & Sheep wool & Rock wool \\
\hline As-received density $\left(\mathrm{kg} / \mathrm{m}^{3}\right)$ & 29.8 & 30.0 & 83.3 & 25.5 & 47.6 & 110.3 \\
\hline Thermal conductivity $(\lambda)$ at $20^{\circ} \mathrm{C}$ in $\mathrm{W} /(\mathrm{m} \mathrm{K})$ & 0.038 & 0.038 & 0.038 & 0.040 & 0.034 & 0.036 \\
\hline Optimum density for minimum thermal conductivity $\lambda\left(\mathrm{kg} / \mathrm{m}^{3}\right)$ & 59 & 48 & 88 & 46 & 79 & 110 \\
\hline Minimum possible thermal conductivity $(\lambda) \mathrm{W} /(\mathrm{m} \mathrm{K})$ & 0.033 & 0.036 & 0.037 & 0.035 & 0.031 & 0.036 \\
\hline Percentage mass increase at $50 \%$ relative humidity & 7.9 & 3.3 & 7.2 & 0.3 & 10.2 & 0.1 \\
\hline
\end{tabular}


of restrictions on its use in the UK [35]. This therefore provides little incentive for the poultry industry to invest in the washing and disinfection processing line necessary to produce appropriate quality clean feathers for use in alternative processes and applications. This makes initial sourcing of suitable raw material difficult and expensive. Short timescales between collection and washing/disinfection are required to ensure feathers do not begin to decompose due to biodegradation.

A second major issue is the size of full-scale industrial air-laid plants. The economies of scale mean that these facilities are large with the smallest typically producing $400-700 \mathrm{~kg}$ of product per hour. This makes initial entry into the market extremely challenging. The alternative is to use toll production facilities to produce lower volumes, but this significantly increases production costs. In addition, the available processing facilities are not necessarily close to where the feathers are generated, or to the end markets for thermal insulation products. This geographical dislocation incurs costs of transporting feathers to the processing facilities and transporting the thermal insulation products to market. This is a significant factor for relatively low density feather-derived products. The economic viability of using feathers is, therefore, dependent on developing an optimised local supply chain with an associated manufacturing cluster.

In the production of appropriate materials for market, a number of other performance and legislative factors need to be taken into account. The fire resistance of thermal insulation materials is clearly a crucial concern [36]. Although viable fire resistant treatments do exist, these will increase costs and undermine the commercial viability of the product. Similarly, another issue experienced by not only feathers, but most natural thermal insulation products, particularly for applications where it is used in a relatively confined space is odour and production of volatile organic compounds (VOCs). Although not necessarily a problem in buildings, this has been identified as a significant barrier to the use of feather-derived products for thermal and sound insulation in automotive industry.

With respect to sustainability, the volume of readily available waste feathers, and their unique natural performance characteristics make a compelling case for exploring use as part of a circular economy. From the perspective of resource use, utilisation of feather waste provides an opportunity to harness an untapped waste stream, at the same time reducing the demand for virgin materials for production of materials from other sources. From the perspective of environmental impact, waste feathers can be used to produce potentially biodegradable natural materials, which could be particularly beneficial if sourcing is optimised as part of a system of industrial symbiosis in association with responsible chicken farmers. Finally, from a perspective of energy use, a great deal of energy is required to clean and transport feather waste, although relatively little energy is needed to produce feather fibres themselves, again offsetting the need for energy to mine and process virgin materials.

As a circular economy for waste feathers does not currently exist, it is necessary to additionally understand the barriers to potential applications. This research found that material characteristics, logistics issues and relevant regulations, make the development of waste feather-fibre insulation products for use in buildings challenging, despite the fundamentally encouraging results obtained from performance characterisation testing. The development of a circular economy may be possible via a range of other applications where the route to market is less demanding than insulation for buildings. These include sustainable feather fibre thermal insulating packaging, oil spill remediation mats, and the use of feathers in specific cryogenic thermal insulation applications. The use of feather-fibre derived products for building insulation products is expected to be problematic if issues with supply chains and processing are not overcome. The development of alterative commercially viable applications with reduced barriers to entry is more likely to provide a circular economy for the feather derived materials developed in this research.

\section{Conclusions}

Cleaned and disinfected feather-fibres can be processed using air-laid technology to form nonwoven products. These have high feather-fibre content and exploit the very low thermal conductivity of feathers to produce new thermal insulation materials. Increasing the density reduces thermal conductivity and a thermal conductivity of $0.033 \mathrm{~W} /(\mathrm{m} \cdot \mathrm{K})$ was produced for samples with a density of $59 \mathrm{~kg} / \mathrm{m}^{3}$ tested at $20^{\circ} \mathrm{C}$. Dynamic water sorption tests on nonwoven feather fibre fabrics show similar performance to commercially available natural fibre insulation products manufactured from denim, hemp and wool. It is, therefore, feasible to manufacture high performance sustainable thermal insulation products from waste feathers with comparable properties to commercially available products. However, several significant technical and commercial barriers associated with the characteristics of feathers, materials processing investment requirements, logistical issues and regulations were identified during the research. These barriers are likely to make commercial development of thermal insulation for buildings from waste feathers highly challenging. Potential alternative applications that could use waste feather-fibres that are associated with an easier route to market are highlighted.

Acknowledgements We acknowledge financial support from the EU programme A2i that funded the thermal insulation testing, and we thank Dr Marcus Yio for help and advice with the DVS testing. The 
research leading to this publication benefitted from EPSRC funding under grant No. EP/R010161/1 and from support from the UKCRIC Coordination Node, EPSRC grant number EP/R017727/1, which funds UKCRIC's ongoing coordination.

Open Access This article is licensed under a Creative Commons Attribution 4.0 International License, which permits use, sharing, adaptation, distribution and reproduction in any medium or format, as long as you give appropriate credit to the original author(s) and the source, provide a link to the Creative Commons licence, and indicate if changes were made. The images or other third party material in this article are included in the article's Creative Commons licence, unless indicated otherwise in a credit line to the material. If material is not included in the article's Creative Commons licence and your intended use is not permitted by statutory regulation or exceeds the permitted use, you will need to obtain permission directly from the copyright holder. To view a copy of this licence, visit http://creativecommons.org/licenses/by/4.0/.

\section{References}

1. Gao, J., Yu, W., Pan, N.: Structures and properties of the goose down as a material for thermal insulation. Text. Res. J. 77, 617626 (2007). https://doi.org/10.1177/0040517507079408

2. Cheong, C.W., Lee, Y.S., Ahmad, S.A., Ooi, P.T., Phang, L.Y.: Chicken feather valorization by thermal alkaline pretreatment followed by enzymatic hydrolysis for protein-rich hydrolysate production. Waste Manag. 79, 658-666 (2018). https://doi. org/10.1016/j.wasman.2018.08.029

3. Reddy, N., Chen, L., Yang, Y.: Biothermoplastics from hydrolyzed and citric acid Crosslinked chicken feathers. Mater. Sci. Eng. C. (2013). https://doi.org/10.1016/j.msec.2012.12.011

4. Tesfaye, T., Sithole, B., Ramjugernath, D., Chunilall, V.: Valorisation of chicken feathers: characterisation of physical properties and morphological structure. J. Cleaner Prod. 149, 349-365 (2017). https://doi.org/10.1016/j.jclepro.2017.02.112

5. Rohen, L.A., Neves, A.C.C., de Mantovani, D.P., Carlos Maurício, F.V., da Silva Vieira, J., de Pontes, L.A., Margem, F.M., Monteiro, S.: Hemp fiber density using the pycnometry technique. In: Ikhmayies, S., et al. (eds.) Characterization of Minerals, Metals, and Materials. Springer, Berlin (2017). https://doi. org/10.1007/978-3-319-51382-9_46

6. Magdalaine, P., Spiess, M.P., Valceschini, E.: Poultry meat consumption trends in Europe. Worlds. Poult. Sci. J. 64, 53-64 (2008). https://doi.org/10.1017/S0043933907001717

7. DEFRA: Poultry and poultry meat statistics. https://www.gov.uk/ government/collections/poultry-and-poultry-meat-statistics

8. Mulder, N.: EU poultry outlook 2025. https://www.mbtt.hu/hirei nk/baromfi_vilagnap_a_baromfiszektor_hosszabb_tavu_kilatasai/ world_poultry_day_nan_dirk_mulder

9. SPIRE: KARMA2020 project proposal. https://www.karma2020. eu/resources/

10. Eslahi, N., Hemmatinejad, N., Dadashian, F.: From feather waste to valuable nanoparticles. Part. Sci. Technol. 32, 242-250 (2014). https://doi.org/10.1080/02726351.2013.851135

11. Molins, G., Álvarez, M.D., Garrido, N., Macanás, J., Carrillo, F.: Environmental impact assessment of polylactide(PLA)/chicken feathers biocomposite materials. J. Polym. Environ. 26, 873-884 (2018). https://doi.org/10.1007/s10924-017-0982-9

12. Sharma, S., Gupta, A.: Sustainable management of keratin waste biomass: applications and future perspectives. Braz. Arch. Biol. Technol. 59, 1-14 (2016). https://doi.org/10.1590/1678-43242016150684
13. Lasekan, A., Abu Bakar, F., Hashim, D.: Potential of chicken by-products as sources of useful biological resources. Waste Manag. 33, 552-565 (2013). https://doi.org/10.1016/j.wasma n.2012.08.001

14. Shanmugasundaram, O.L., Syed Zameer Ahmed, K., Sujatha, K., Ponnmurugan, P., Srivastava, A., Ramesh, R., Sukumar, R., Elanithi, K.: Fabrication and characterization of chicken feather keratin/polysaccharides blended polymer coated nonwoven dressing materials for wound healing applications. Mater. Sci. Eng. C. 92, 26-33 (2018). https://doi.org/10.1016/j.msec.2018.06.020

15. Tesfaye, T., Sithole, B., Ramjugernath, D., Chunilall, V.: Valorisation of chicken feathers: application in paper production. J. Clean. Prod. 164, 1324-1331 (2017). https://doi.org/10.1016/j. jclepro.2017.07.034

16. Al-Asheh, S., Banat, F., Al-Rousan, D.: Beneficial reuse of chicken feathers in removal of heavy metals from wastewater. J. Clean. Prod. 11, 321-326 (2003). https://doi.org/10.1016/S0959 $-6526(02) 00045-8$

17. Mézes, L., Tamás, J.: Feather waste recycling for biogas production. Waste Biomass Valoriz. 6, 899-911 (2015). https://doi. org/10.1007/s12649-015-9427-7

18. Wattie, B., Dumont, M.-J., Lefsrud, M.: Synthesis and properties of feather keratin-based superabsorbent hydrogels. Waste Biomass Valoriz. 9, 391-400 (2018). https://doi.org/10.1007/s1264 9-016-9773-0

19. Berardi, U., Iannace, G.: Acoustic characterization of natural fibers for sound absorption applications. Build. Environ. 94, 840-852 (2015)

20. Pargana, N., Pinheiro, M.D., Silvestre, J.D., de Brito, J.: Comparative environmental life cycle assessment of thermal insulation materials of buildings. Energy Build. 82, 466-481 (2014). https:// doi.org/10.1016/j.enbuild.2014.05.057

21. Asdrubali, F., D’Alessandro, F., Schiavoni, S.: A review of unconventional sustainable building insulation materials. Sustain. Mater. Technol. 4, 1-17 (2015). https://doi.org/10.1016/j.susma t.2015.05.002

22. Palumbo, M., Lacasta, A.M., Holcroft, N., Shea, A., Walker, P.: Determination of hygrothermal parameters of experimental and commercial bio-based insulation materials. Constr. Build. Mater. 124, 269-275 (2016). https://doi.org/10.1016/j.conbuildma t.2016.07.106

23. D’Alessandro, F., Baldinelli, G., Bianchi, F., Sambuco, S., Rufini, A.: Experimental assessment of the water content influence on thermo-acoustic performance of building insulation materials. Constr. Build. Mater. 158, 264-274 (2018). https://doi. org/10.1016/j.conbuildmat.2017.10.028

24. Pathak, C.S., Mandavgane, S.A.: Applicationof recycle paper mill waste (RPMW) as a thermal insulation material. Waste Biomass Valoriz. 10, 2343-2352 (2019). https://doi.org/10.1007/s1264 9-018-0235-8

25. Ducoulombier, L., Lafhaj, Z.: Comparative study of hygrothermal properties of five thermal insulation materials. Case Stud. Therm. Eng. 10, 628-640 (2017). https://doi.org/10.1016/j.csite .2017.11.005

26. El Wazna, M., El Fatihi, M., El Bouari, A., Cherkaoui, O.: Thermo physical characterization of sustainable insulation materials made from textile waste. J. Build. Eng. 12, 196-201 (2017). https://doi. org/10.1016/j.jobe.2017.06.008

27. Patnaik, A., Mvubu, M., Muniyasamy, S., Botha, A., Anandjiwala, R.D.: Thermal and sound insulation materials from waste wool and recycled polyester fibers and their biodegradation studies. Energy Build. 92, 161-169 (2015). https://doi.org/10.1016/j. enbuild.2015.01.056

28. Paşayev, N., Kocatepe, S., Maraş, N.: Investigation of sound absorption properties of nonwoven webs produced from chicken 
feather fibers. J. Ind. Text. 48, 1616-1635 (2019). https://doi. org/10.1177/1528083718766843

29. Dieckmann, E., Nagy, B., Yiakoumetti, K., Sheldrick, L., Cheeseman, C.: Thermal insulation packaging for cold-chain deliveries made from feathers. Food Packag. Shelf Life. 21, 100360 (2019). https://doi.org/10.1016/j.fpsl.2019.100360

30. Casadesús, M., Álvarez, M.D., Garrido, N., Molins, G., Macanás, J., Colom, X., Cañavate, J., Carrillo, F.: Environmental impact assessment of sound absorbing nonwovens based on chicken feathers waste. Resour. Conserv. Recycl. 149, 489-499 (2019). https://doi.org/10.1016/j.resconrec.2019.06.009

31. Bessa, J., Souza, J., Lopes, J.B., Sampaio, J., Mota, C., Cunha, F., Fangueiro, R.: Characterization of thermal and acoustic insulation of chicken feather reinforced composites. Procedia Eng. 200, 472-479 (2017). https://doi.org/10.1016/j.proeng.2017.07.066

32. Abdou, A., Budaiwi, I.: The variation of thermal conductivity of fibrous insulation materials under different levels of moisture content. Constr. Build. Mater. 43, 533-544 (2013). https://doi. org/10.1016/j.conbuildmat.2013.02.058
33. Karamanos, A., Papadopoulos, A., Anastasellos, D.: Heat transfer phenomena in fibrous insulating materials. In: Proc. 2004 WSEAS/IASME Int. Conf. Heat Mass Transf. 7 (2004)

34. Dieckmann, E., Dance, S., Sheldrick, L., Cheeseman, C.: Novel sound absorption materials produced from air laid nonwoven feather fibres. Heliyon. 4, e00818 (2018). https://doi. org/10.1016/j.heliyon.2018.e00818

35. Chojnacka, K., Górecka, H., Michalak, I., Górecki, H.: A review: valorization of keratinous materials. Waste Biomass Valoriz. 2, 317-321 (2011). https://doi.org/10.1007/s1264 9-011-9074-6

36. Hidalgo, J.P., Welch, S., Torero, J.L.: Performance criteria for the fire safe use of thermal insulation in buildings. Constr. Build. Mater. 100, 285-297 (2015). https://doi.org/10.1016/j.conbuildma t.2015.10.014

Publisher's Note Springer Nature remains neutral with regard to jurisdictional claims in published maps and institutional affiliations.

\section{Affiliations}

\section{Elena Dieckmann ${ }^{1,2,4} \cdot$ Richard Onsiong $^{4} \cdot$ Balázs Nagy $^{3} \cdot$ Leila Sheldrick $^{1} \cdot$ Christopher Cheeseman $^{4}(1)$}

1 Dyson School of Design Engineering, Imperial College London, London SW7 1NA, UK

2 Aeropowder Ltd, London, UK

3 Department of Construction Materials and Technologies, Budapest University of Technology and Economics, Budapest, Hungary
4 Department of Civil and Environmental Engineering, Imperial College London, London SW7 2BU, UK 